Portland State University

PDXScholar

7-26-2019

\title{
Post-Colonial Fantasy and Intersectional Heroism within Who Fears Death
}

Miranda Hubbard

Portland State University Honors College

Follow this and additional works at: https://pdxscholar.library.pdx.edu/honorstheses Let us know how access to this document benefits you.

Recommended Citation

Hubbard, Miranda, "Post-Colonial Fantasy and Intersectional Heroism within Who Fears Death" (2019).

University Honors Theses. Paper 780.

https://doi.org/10.15760/honors.798

This Thesis is brought to you for free and open access. It has been accepted for inclusion in University Honors Theses by an authorized administrator of PDXScholar. Please contact us if we can make this document more accessible: pdxscholar@pdx.edu. 


\title{
Post-Colonial Fantasy and Intersectional Heroism within Who Fears Death
}

\author{
By \\ Miranda Hubbard \\ An undergraduate honors thesis submitted in partial fulfillment of the \\ requirements for the degree of \\ Bachelor of Arts \\ in \\ University Honors \\ and \\ English
}

Thesis Advisor

Anoop Mirpuri, Ph.D.

Portland State University

2019 
Historically, speculative fiction has been lauded as a subversive, critical medium. In practice, however, its societal critiques can be so allegorically swaddled that they avoid confronting real-world systems of inequality. In some instances, the otherworldly nature of speculative fiction provides a necessary guise of plausible deniability which can enable singularly resistant narratives to be published where censorship is rampant--like the political, at times anti-Soviet messaging embedded in the work of Russian sci-fi authors Yevgeny Zamyatin, or brothers Arkady and Boris Strugatsky. In other contexts, such as the defamiliarization of historical traumas associated with colonialism, this coy, allegorical approach borders on problematic. As Mark Bould notes in his article on Afrofuturism and Black SF: [...]the satirical sf tale in which the alien or android is the subject of prejudice, whatever its merits, also avoids direct engagement with the realities of racialized hierarchies and oppressions. (179)

Systems of oppression, when used to inform the experiences of non-human characters, neglect the subjectivity of real-world peoples impacted by them. For the subject of slavery in speculative fiction, the defamiliarization often built into the medium reduces the complex and traumatic existence of slavery to something simpler, more easily consumable, and devoid of the voices of those subjugated by it.

Nnedi Okorafor's groundbreaking novel, Who Fears Death, resists defamiliarizing the reader from its universe. The world of the novel may be fictional, may be magical, but it does not provide escape from real societal wrongs, inequalities, and structures. Rather than using fantastical elements as stand-ins for systems of inequality, this novel uses fantasy as a tool to break down explicit oppressive structures. This would be noteworthy even without speculative fiction's history of endorsing colonialist ideologies. 
Genres such as science fiction and fantasy[...]have long and deeply problematic histories of depicting conquest and colonialism as glorious enterprises, and they also often engage in the othering of indigenous people to the point where the latter become nonhuman: that is to day, they appear only as aliens. Even when speculative fiction attempts to critique colonialism, it has often simultaneously reified the problematic assumptions underlying the colonial project. (Burnett 134) What Burnett outlines in his essay on Okorafor's work, and what I will reference in my own, are the ways in which Okorafor engages with, navigates, and complicates a vision of the postcolonial future. Burnett's argument is structured largely around her novels Who Fears Death, and The Shadow Speaker. Through the application of Afrofuturist theory and post-colonial scholarship, he positions Okorafor's novel as both “a post-colonial revision of speculative fiction and a speculative revision of post-colonialism” (132). His work is illuminating for its thorough post-colonial analysis, and the attention he brings to Okorafor's work highlights the significance of Who Fears Death, and how it advances the genre of speculative fiction and engages with broader post-colonial dialogue. What is not included in his arguments, and what will be the crux of this essay, is the intersectional experience embedded in the narrative and form of this novel. Its representation of marginalization is intersectional--characters face challenges presented by the intersecting systems of patriarchy and colonialism. Its engagement with genre is intersectional-the setting is a post-apocalyptic future Africa, yet magic (and some more specific narrative and compositional elements) link it to fantasy. Together, the conflict and stakes of a fantasy epic become inextricable from the protagonists' navigation of a hostile world. This essay will first map the construction of Okorafor's races using race- and fantasy-theory. Then, it will analyze how the oppressive colonizer/ colonized dynamics become the stakes of the novel, and what 
meaning that carries for real-world solutions to systemic inequality. This analysis will continue into the form of Who Fears Death, from the complicating significance of the narration, to how the novel and its heroine of color engage with the fantasy genre. Ultimately, each aspect communicates a larger story--this novel engages with multiple levels of genre conventions and societal structures to create a complex, and rather optimistic, new kind of narrative. Who Fears Death is an exercise in intersectionality, blending genre, race theory, and feminism to interrogate questions of authorship, agency, and identity within a patriarchal, colonialist society.

\section{$\underline{\text { Racial Signifiers and Other Fictional Constructs }}$}

In his seminal essay “The Spectacle of the Other,” Stuart Hall explores the phenomenon of "Othering” in media, specifically how divisions in identity between dominant "in" groups and oppressed "out” groups become societal narratives which justify oppression (325). The othered "out” group is assigned characteristics and traits by the dominant culture, as well as attached signifiers which can be used to enforce or corrupt the stereotypes assigned to them. These signifiers can be labeled as positive or negative by the othering group--such as stereotypes of indigenous peoples being noble or connected to nature, or Asian-Americans being good at math, or conversely stereotypes of African-Americans being lazy or Jews being greedy. While the dominant group may value these traits differently, they are all facets of othering, and function to oppress and separate the othered group from the whole. Each trait contributes to a generated narrative outside of the othered communities, alienating them from the dominant society and impacting how they are treated and evaluated by the world around them.

The othered communities Hall identifies have forced onto them sets of values and identities which present conflicting, binary forms of representation. These binaries can be 
enforced or complicated by racial signifiers. The signifiers that Hall highlights are particularly visible in Okorafor's narrative strategies. In her worldbuilding, specifically in its racial structures, Okorafor employs similar qualitative binary traits that are prescribed to the races by the dominant societal text. Practically speaking, the binaries of her colonizer and colonized races are pulled from real-world colonialist qualitative signification. Within the Great Book, which acts as the bible of the world, there are direct connections made between the Nuru and Okeke peoples and (respectively) "images of light and dark,” "Beauty and ugliness,” "Clean and dirty,” and "Good and evil" (Okorafor 318). These binaries of signification written into the Great Book are transposed straight from our own current-day cultural narratives. For Who Fears Death, they serve as a jumping off point toward a post-colonial world--shackles to be shed in order to begin anew.

Okorafor utilizes the trickster trope of "signifying" as a way of complicating simplistic postcolonial narratives of good/colonized/bad/colonizer while still maintaining a strong critique of colonialism, and she deploys the speculative trope of a post-apocalyptic landscape to articulate a way forward beyond our current neocolonial reality. (Burnett 134)

The signification Burnett refers to involves employing these warped, but still recognizable colonial binaries in the racial landscape of her world. The races of Okorafor's world maintain oppositional associations, generated by the colonialists who build racial identity through contrast to the colonized. Okorafor's utilization of signifiers, and the way she grapples with racial signification within colonial society, challenges colonialist narratives while providing a more nuanced and complex vision of a postcolonial state. 
While the identity of both the oppressor and the oppressed are assigned unfamiliar terminology, their humanity is unquestionable; the fictional races Okeke and Nuru are directly tied to our real-world African and Arabic peoples. Their behaviors are not abstracted by fictional cultures or species dynamics--they are human, their struggles are human, their good and bad is an aspect of their humanity. The division between Nuru and Okeke is introduced with physical signifiers, but extends to qualitative societal narratives--Nuru are associated with good, with being of the light, as the righteous rulers of the realm; Okeke are associated with night, with mischief, with subjugation. True to real-world race theory (Johnson 136), Nuru identity is constructed as a reaction to prescribed Okeke signifiers, developed to contrast the coloniallydefined stereotypes of the Okeke. The racial divisions established in the Great Book dictate that Ani, the goddess of the world, created the Okeke even before she created the day (so their skin is the color of night), and that later, the Nuru arrived from the stars (so their skin is the color of sun). The Book also stipulates that "Okeke were born to be slaves of the Nuru. Long ago, during the Old Africa Era, they had done something terrible to cause Ani to put this duty on their backs" (16). The Great Book presents, for both Nuru and Okeke, a theological justification for the enslavement of Okeke.

Straddling the border of this racial boundary are Ewu, children born of one Nuru parent and one Okeke parent. To the Nuru, they are nothing. The Okeke treat them as outsiders, generally regarding them with disgust and contempt--their hatred is complicated, as Ewu are a physical represention of the Okeke subjugation by the Nuru. In many villages, Ewu women are subjected to sexual violence, being forced to work as prostitutes, and raped without the chance of retribution. Both our heroine Onyesonwu and her partner Mwita were born Ewu, though through different circumstance. 
There is a precedent in fantasy for fictional peoples to carry racial signifiers rooted in the real world.

In science fiction, otherness is often conceptualized corporeally, as a physical difference that either signposts or causes an essential difference, in a constant echo of zero-world racialization. Although this concept of alienness does not always signify a colonial relationship, it often dovetails with the colonial discourse[...](Langer 82). This excerpt, taken from Jessica Langer's book Postcolonialism and Science Fiction, highlights the trend of real, "zero-world" racial signification finding its way into fictional narratives. This can look like Elves carrying Western European racial signifiers, such as fair hair, and pale skin; as orcs with broad noses, wide lips, and violent sensibilities; or as Goblins, with hooked noses and a greed for gold. Unconsciously or intentionally, physical and cultural traits in fantasy races signify parallel to real-world racial stereotypes.

Within Who Fears Death, Okorafor's races are intentionally rooted to extant groups. Their associations draw on, rather than racial stereotypes, real world histories of subjugation and oppression. These histories are the foundation for the theological and colonialist structures of Okorafor's world--Onye's outsider status is repeatedly reinforced as her character defies societal narratives and undermines expectations. The greater evil she combats turns out to be the oppressive narrative used to justify Nuru dominance. To fix her world, she must not only defeat her father, the sorcerer Daib (and by extension the colonizer within her), but rewrite the master narratives which subjugate the Okeke.

Onye goes much of the novel convinced that killing her father is the ultimate goal of her quest. She attacks him repeatedly, and suffers for it, but as strong as she becomes, he is stronger. The violence and hatred she reciprocates for him only leave her mangled, with Mwita left to 
patch together the pieces. While within her subjective lens, killing her father is her objective, in practice meeting violence and hatred with like only hurts Onye and lends strength to her father. The novel presents a different win condition for Onye--the prophecy about her is that she will be the one to rewrite The Great Book (318). Victory and the societal change it generates are not gotten by eliminating the hateful light-skinned man who embodies evil; Daib is a particularly toxic symptom of a systemic problem. The real obstacle to utopia is the dominant narrative of inequality propagated by the Great Book--it's the master narratives that enforce the subjugation of the Okeke. Its message permeates the experiences of every character in the novel, particularly Onyesonwu and Mwita, who as Ewu are seen as a representation of the oppressive violence of the Nuru. By rewriting the Great Book, Onyesonwu is meant to free her people from oppression. The symbolism of rewriting the narratives of inequality from the Great Book is elegant in its simplicity. Ostensibly, before the Book is changed, Nuru should treat Okeke with bigotry, yet when Onyesonwu, Mwita, and Luyu reach the Nuru city, however, Luyu is not greeted with hatred. The Nuru make her do labor, like carry bolts of fabric (356), sweep out a stall, model a dress, and pour noxious fuel (357), but they are not openly cruel to her. The economic motivation behind Okeke enslavement is briefly apparent.

However, when The Great Book is rewritten, we see the racial utopia that Onye has been striving for is achieved, with "Nuru, Okeke, and two Ewu children in school uniforms playing[...]paved roads populated by men and women, Okeke and Nuru, riding scooters” (386). The act of rewriting the ideological foundation of the Great Book not only erases the subjugating master narratives, but the institutional racial inequalities that facilitated their colonial society. This somewhat idealistic solution to the institution of slavery is an optimistic idea that would not sit well with race theorists like Walter Johnson, who would argue that racial constructs are 
generated within economic structures which rely upon them, and not the other way around. Still, the plot-driven takedown of an oppressive dominant narrative is innovative, and speaks to the novels politicized positioning within the historically colonial realm of speculative fiction.

\section{Intersecting Identity and Authorship in Who Fears Death}

Okorafor's novel is written largely within the fantasy genre, but more specifically within a post-apocalyptic Africa. While Who Fears Death engages with the conventions of multiple genres, it denies them sovereignty over the narrative. It engages with the conventions of fantasy, a genre with a foundation and legacy of white male perspectives, and subverts them. By utilizing the tools of fantasy, Okorafor creates incredibly complicated and nuanced oppressor/ oppressed narratives, as well as generates rich, intersectional identities which wield agency over their environments.

Shifting the perspective away from the prototypical masculine European hero, Who Fears Death privileges the narrative of a powerful feminine African heroine, and in doing, so dewesternizes and reshapes the hero's journey to reflect the intersectionality of its protagonist. By intersectionality, I refer to the intersecting marginalized racial and gender identities that Onyesonwu, our heroine, must navigate. Kimberle Crenshaw, who coined the term, observed “[...]how the experiences of women of color are frequently the product of intersecting patterns of racism and sexism[...] Because of their intersectional identity as both women and of color within discourses that are shaped to respond to one or the other, women of color are marginalized within both” (1242). As an Ewu woman, Onyesonwu navigates the intersection between oppressed identities. As highlighted by Crenshaw, the protagonist faces prejudice from her female friends for being Ewu, from her Ewu partner for being a woman, and from everyone else 
in power for some combination of the two. She is not only written with an intersectional identity, but she is written into a world which illustrates the complex, intersecting marginalizations that come with it.

Nnedi Okorafor's work engages with layers of convention that generate meaning on multiple levels. Like her protagonist, her genre is intersectional. The world of Who Fears Death exists as an almost future Africa, with elements which place it somewhere between postapocalyptic Sudan and a new, fantasy realm. Technology exists, some more futuristic than exist in our present world, some as familiar as a GPS or a video recorder. These devices are vestiges of a technologically rich past, contrasting sharply against the somewhat magical, rural life in the villages of the novel. Advanced technology, magic, and tradition are threaded together, creating a world where the boundaries between past and present, old and new world technologies, are inextricable. Nuru ride motorcycles, Onye and her crew travel with camels. Onye's mother survives in the desert with her baby, playing handheld videogames to pass the time (23), and eventually teaching her (older) daughter songs that call wildlife to her like Snow White (29). Myth and science each find a place in this universe, side by side, often together, and each given the same treatment. Despite the inclusion of elements from disparate genres, the only constant in the text of Who Fears Death its intersectionality. The product is something transcendent, intersectional in a way that denies any genre supremacy. It engages with structures, but fundamentally exists as a model for resistance. Onyesonwu's hero's journey is inseparable from her journey as a young woman of color.

While the genre and protagonist alone illustrate an intersectionality that complicates schematic interpretations, the form introduces another level of reading which questions authorship and complicates the optimistic arc of the novel. On the one hand, here we get a story 
written in first person through the voice of a heroine of color. Not only does the narrative center a perspective marginalized both inside and outside the universe of the novel, but it gives said voice control of its own representation. As Anh Hua notes, "By writing one’s self into history and narrative using autobiographical stories and by making history and writing one's identities into imaginative landscapes, whether realistic or imaginary, one can achieve narrative empowerment, especially for those subjects who must constantly struggle against the repression of their being and becoming” (37). According to Hua, creating stories that represent black, female identity are a way of resisting erasure--the sheer presence of marginalized identities within written text can be an act of resistance, of empowerment. Who Fears Death exemplifies this representation by writing a woman of color into the role of fantasy hero in a realm simultaneously realistic and imaginary. The predominant perspective privileged in this text is that of Onyesonwu, the $E w u$ heroine; second is the brief section which features an omniscient third person perspective following her mother as she is raped, and carries and raises her daughter in the desert. These main characters are women of color, who at times experience sexual violence, hatred, and scorn. Their position in the society of the novel makes them vulnerable to violence, but it never strips them of their personhood or their agency--we follow these women through and out of the margins their society actively tries to contain them within.

On the other hand, there is an aspect to the narration which complicates the asserted authorship of the voice. What we as readers are receiving, according to the telegraphing of the narrator, is the story Onyesonwu is telling to a "sympathetic" Nuru journalist who has come to collect her confession while she awaits her execution (165). Everything we read is, ostensibly, the story transcribed onto this Nuru man's laptop. By this structure alone, the novel complicates understandings of authorship, of voice, and of who controls representation. While the first- 
person perspective promises unmediated voice, the form repeatedly reminds us that this narrative is being filtered through the laptop of a Nuru man. Functionally, this places us in the perspective of the colonizer, an outsider perhaps sympathetically, perhaps voyeuristically, peeking behind the curtain.

By Onye addressing her audience, the Nuru journalist, Okorafor positions the reader as Nuru--the colonizer identity extends to the reader. The audience of Okorafor's story is othered by this fantasy epic, just as marginalized identities have been othered by fantasy in years past. By analyzing Who Fears Death through conventions of distinctly white-dominated genres of speculative fiction, we chance viewing a de-Westernized story through a distinctly Western lens. This is a sin of academic scholarship, and risks undermining one of the strengths of Afrofuturism, which is to reclaim and control the narrative of people of color in the future. As Afrofuturist author Nalo Hopkinson notes, however, post-colonial fiction authors produce stories that "take the meme of colonizing the natives and, from the experience of the colonizee, critique it, pervert it, fuck with it” (9). The structures of the genre become tools of subversion, methods to communicate complex societal critiques and present new ways forward. In the true spirit of claiming her narrative, Onye's character is taking the opportunity to advocate for herself, modeling a discourse that seeks to empower marginalized narratives.

The parallels to Thomas R. Gray’s The Confessions of Nat Turner are hard to ignore. Each are narratives of a captured person of slave class, who led a rebellion against their oppressors. Each narrative is a confessional, spanning the scope of the subject's life, being confessed as they sit in a jail cell awaiting execution. Each is purportedly their own words, but is admittedly narrated by a journalist who entered the cell. While presenting the condemned perspective in first person, both texts intersperse reminders of their light-skinned transcriber; 
with Nat Turner, this is the introduction by Thomas Gray, as well as the "Question--" and "Ans--

" intrusions peppered through Turner's narrative; with Who Fears Death, these are the italicized sections where Onye addresses the journalist directly. “Anyway, I'm glad to see you, but why do you risk coming here? There's a reason with you, isn't there? No Nuru man would do this without a reason that goes beyond curiosity" (165). At first, it seems counterintuitive that such an empowered narrative would take this step to destabilize the authorship of the protagonist. It certainly complicates the narrative of the protagonist, positioning her in a charged cultural myth of resistance and rebellion, and rooting the novel's story within American colonial history.

\section{Who Fears Death as Intersectional Fantasy Epic}

The mythic structure of Who Fears Death, coupled with the first person narration, positions the narrative of Onyesonwu as self-generated oral storytelling. With the mediation of the Nuru journalist, this myth is externalized, generated from an ally coopting Onye's resistant narrative arc. The ambiguity of the narration complicates whether Onye's mythic positioning is a product of colonizer or colonizee, yet either interpretation places the narrative as an act of mythmaking. According to Brian Attebery, fantasy as a genre is one of the predominant ways in which contemporary Western society maintains a relationship with myth (9). Within colonialism, however, retelling and continuing myths can also be a method for colonized cultures to resist erasure (Attebery 10). The very form the book takes, with it’s complicated, layered narrative, imbues it with the de-westernized significance of oral history, while linking it firmly to the fantasy genre. Further, each aspect of fantasy featured within the novel is complicated by and inextricable from Onyesonwu's intersectional identity. 
True to the larger tenets of the fantasy genre, the protagonist, Onyesonwu, is faced with a series of choices that affect the moral trajectory of her character. Nnedi Okorafor's work interrogates notions of good and evil, of hero and villain; her novel contains a series of choices which continuously threaten to tarnish the integrity of the heroine. This struggle is typical of fantasy. As John H. Timmerman observes in his book, Other Worlds: The Fantasy Genre, "the fantasy hero must choose, but his choices have repercussions beyond himself and he is keenly aware of this before choosing” (72). Okorafor's fantasy heroine, Onyesonwu, is the exemplar of this choice, and yet her ability to cleave a moral path is shaped by her racial identity within her society. Following the fantasy motif, here we have a character whose magic will cast her as villain or as hero--whose choices inform her alignment, and whose power bestows upon her the agency and freedom to choose. This binary of good/evil moral signification intersects with the racial signification she functions within. The Nuru, the colonizers, exist in the universe carrying the associations of good, while the enslaved Okeke are seen as evil. Their very skin condemns them to moral judgments before their actions have a chance to intervene. Children conceived by Nuru men raping Okeke woman are known as Ewu. Their physical markers are regarded as ugly within Okeke culture; more importantly, because of their often violent conception, they are considered prone to violence. Onyesonwu, and her life companion Mwita, are both Ewu (though only Onye is conceived of rape). As hero, Onyesonwu's acts beget meaning not just from their weight, but because of the weight placed on her by society because of her race. Onye's struggle is not only between good and evil, but between her own identity, and the qualitative binaries projected onto her race.

The challenges she navigates, too, are brought about from her confrontations with the prejudice and bigotry of people she meets. Onye grapples repeatedly with restraining herself 
from using her magic for violence. She blinds a village after they stone her friend, Binta (240). She attacks Aro, the village sorcerer, when he refuses to teach her because of her gender (105). She forces her home town of Jwahir to watch and experience a vision of her mother's rape, after they express apathy towards the violence happening where the Okeke are actively enslaved (151). Her violence is reactive and vengeful, her rage validated by her experience and by her circumstances--often she and the people she loves are threatened, hurt, and discriminated against. She is the product of rape and carries the trauma of her mother. In one instance, she herself is almost raped by a group of Okeke men who mistake her for a prostitute because she is $E w u$. She is dragged to an alleyway, surrounded by men. To push them off, she conjures the wind.

The wind kept Mwita back. "Remember," he shouted, "This is not what we are. No violence! It’s what sets us apart!"

I began to tremble as my fury retreated and clarity set in[...]They cowered on the ground. Terrified of me. (205)

Here is a moment where, morally speaking, Onye's murder of these attempted rapists could be seen as a justifiable punishment for their crimes (Lichtenberg 5). The retaliation is based on the wrongs that have already occurred, and the punishment would protect any Ewu women these men might try to rape in the future. And yet, Onyesonwu spares all of their lives. During the novel, her lover Mwita often acts as moral compass, guiding Onye to be less destructive with her gifts. It is the voice of Mwita, who anchors Onye to a tempered moral trajectory. It is the voice of Mwita which guides Onye to self-awareness of her own power, and helps her chose actions which maintain her alignment. As Ewu, both Onye and Mwita fight against the prejudices associated with their identity. Their actions, however individual, reflect upon all Ewu in the eyes 
of prejudicial Okeke. Unlike the white male heroes of much of the fantasy genre, Onye's actions are curtailed by her intersectional identity--she bears the burden of representation.

Onyesonwu's identity as a heroine is another major intersection in her experience. Her role as saviour is based upon her ability to confront her rapist Nuru father, and to rewrite the problematic messages of the Great Book. Unlike her friends, she can regrow body parts, and unlike other Ewu women, she can defend herself from being raped. Unlike her female friends or her Ewu companion, she can change her body into that of a vulture and escape.

The distinctions between this intersectional heroine and the more normative hero can also be seen in Onye's interactions with the Hero's Journey, a narrative trajectory dating back thousands of years, outlined by Joseph Campbell, and heavily utilized in the epic fantasy genre. True to form, Onyesonwu is an unusually powerful young hero set to fulfill a prophecy. She begins in her ordinary world, Jwahir, where she and her family eke out an unlikely peace. From there, she transitions into womanhood, which coincides with her coming into her power. She seeks the help of the village sorcerer, who eventually provides, than ventures out on a quest with her cadre of allies to defeat her nemesis, a great yet evil sorcerer who happens to be her own father. Each aspect of her journey, from her seeking a mentor to her feats and trials, is connected to her experience as an Ewu woman.

The first inkling of her power comes during her eleventh year, when she accidentally transforms into a sparrow. After she is coaxed down from a tree, her mother Najeeba tells her the story of her rape, and her subsequent years wandering the desert, carrying and raising Onyesonwu. Around this same time is Onye's first menstruation, development of breasts, and her "Eleventh Rite” circumcision, during which her spirit leaves her body and enters the spirit plane where her evil sorcerer father can find her. This tangle of magic, connection, and peril are all 
linked to her transition into womanhood within her community. Unlike the other girls in her village, her magic shapes her experience, both empowering and endangering her. Folded into her eleventh year is her entry into pubescence and her first manifestation of magic--as a woman and as a sorceress, she comes into a preliminary adulthood. This transformation aligns with the first stage of the hero's journey, known as the "Call to Adventure", in which the hero is recruited to solve a problem, conquer a challenge, and go on an adventure. Establishing scenes like this lay the foundation for her status as woman, and hero. By anchoring the beginning of her hero's journey to her nacent womanhood, her heroism is intertwined with her gender. Her emergence as a fantasy hero is inextricable from her transition into a gendered adulthood; her femininity is inseparable from her power.

This is one of the earliest examples of her own intersectional heroism. Her coming of age as woman and hero are the same moment. While her hero's journey is palpable, Okorafor's protagonist deviates from the white, male norms of the hero's journey. Further, Onye's gender and racial identity affect her ability to engage with the stages of the journey. They impact the way she engages with her enemies and her allies. Traditionally, "Meeting with the Mentor" in a hero’s journey involves a sagely, Merlin-esque figure who whisks the up-and-coming hero under their wing. Onye, by contrast, is repeatedly rejected by the village sorcerer, Aro, and only earns his mentorship after she attacks him in his home. During this scene, something cracks in Onye, which takes her from victim to agent of her own vindication. "Protecting myself is a useless endeavor, I thought. I had to somehow find the man who harmed my mother, the man who hunted me. I had to hunt him. And when I find him, I thought, I'll kill him” (105). In this moment, Onyesonwu has accepted the Call to Adventure. While for her, this call is to kill her father, her journey will call upon her to fix the inequalities of her society by rewriting the Great 
Book. Onye’s heroism works towards creating an egalitarian world. Directly following this revelation is the realization to why Aro has been spurning her as a student. “'You... you won't teach girls or women because you're afraid of us! Y-y-you fear our emotions.” I giggled hysterically and then grew serious. "That is not a good enough reason!” (ibid).

Onye's acceptance of her quest comes in tandem with her comprehension of the difference in society's reaction to her because of her womanhood. Her new trajectory is informed not just by her mother's trauma, but by her own mistreatment by men in power. She mauls Aro's spirit for refusing her because of his own misogyny. In the time after, word spreads through the village about who attacked him. The rumors tell that it was an Ewu, which places both Mwita and Onye under suspicion. "People repeated it to each other: Ewu children are born from violence and so it's inevitable that they would become violent” (107). The people of Jwahir, who know even peripherally Onye and Mwita, cannot see past their race to even distinguish their actions from each other, much less $E w u$ as a whole. Again, we see the personal, individual actions of Onye are refracted across the totality of her identity. Further, we see the intersections of her experience, with her retaliation against gendered prejudice being racialized by onlookers in her community.

Ultimately, her mauling of Aro is one of the main factors that convince him to take her on as a student.

"I'll teach you the Great Mystic Points, if it is willed," he said. "You're a danger to us all if I don't. You're a danger to us all if I do, but at least I'll be your Master” (109).

In her attack on him, she confirms his opinion of her as volatile and emotional. She never really escapes his misogyny, but she leverages it to make him open the door to her. A part of the 
intersectional representation of Onye comes from the way her marginalized identities interact with the communities she is a part of. Her womanhood informs what she must go through to earn her mentorship. Her Ewu skin affects her friendships, as well as her relationship with the Okeke communities that she is fighting to protect. The novel conveys nuanced representations of bigotry, and enacts discrete solutions to its different manifestations. Prejudice finds her through both the strangers who read the racial signifiers off her skin, and the Okeke friends who support her, love her, and leave their homes and lives behind to follow her for miles into the desert. She is shown disgust, resentment, and fear from both those she hates and those she loves, and she must learn to be strong in the face of their prejudice. Not only do Onye’s most loyal allies demonstrate internalized racism against her mixed parentage, but they are then given the space to correct. After Aro accepts Onye into his tutelage, he apologizes to her for being “arrogant,” "insecure," and "a fool” for refusing her because she is a girl. Their bond becomes stronger as Aro dismantles his assumptions, and even after Onye leaves, his views on teaching women are changed. He even ends up taking on Onye's mother as a student once Onye has journeyed away from home (286).

When Onye is sent through the magical rite of passage known as The Great Mystic Points, the sorcerer who initiates her is Sola. Again, we see a necessary gatekeeper to her progression as a hero, rejecting her based on gender. Sola displays disgust at her body, and contempt at her gender. “'Aro calls me here and a female sits before me,' he said. He flared his nostrils. 'One who will bleed soon. Very very soon. This place is sacred, you know.'” (125) He treats her imminent menstruation as something that makes her unclean. Her success at the points proves him wrong, though, and he is forced to confront his prejudice. Later in the text, he also asks forgiveness from her: 
"You must forgive us all for our weaknesses, me, Aro, all of us old ones. We'll learn from this. Aro refused you because you were an Ewu female. I almost did the same. This Seer, Rana, guards a precious document. This was why he was given the prophecy. He was told something and couldn't accept it. His stupidity will give you a chance, I think."

I sighed and held up my hands[...]

"Rana couldn’t believe what he was told, apparently. He wasn’t advised to look out for a Nuru man. It was an Ewu woman," he said. (161)

The representation of inequality is multi-tiered and complex. Further, the solutions Onye pursues are nuanced and situational. Hatred and ignorance sometimes comes from the closest, most intimate relationships Onye has, and the novel provides space for those prejudices to be confronted and addressed. In this way, the novel communicates solutions which are, when the context demands, communal and constructive. The problem-solving for these conflicts is markedly different from the problem-solving for large scale conflicts, like her racist, misogynist, abusive, powerful father. The existence of a nuanced, intersectional identity as the hero of a fantasy narrative matters. Each of these instances of prejudice interfere with her ability to access the resources to fulfill the quest she was prophesied to fulfill. The contrast between the white, male, normative hero's journeys and Onye's journey carries didactic momentum towards communicating systems of privilege and oppression in our current society.

As a cisgender woman, Onye's experience in the world is fundamentally different. Her experience as a vagina-having individual is reflected in the plot, where she experiences periods, female circumcision, and pregnancy. Her bodily experience is emphasized and normalized within the narrative, within her relationship with herself and within the network of women she 
interacts with. Female pleasure is emphasized, through her growing back of her own clitoris, and taking time to regrow the clitorises of her friends. Binta, Diti, and Luyu (her Eleventh-Ritebonded female friend group) are shown actively seeking pleasure and sex for their own satisfaction, and Onye's physical relationship with Mwita is reciprocal, emotional, and functions to help Onye stay grounded. Sex exists in this novel as a positive experience, emphasizing female pleasure, and completely distinct from sexual violence.

While the patriarchal structures in the book fear and control women's bodies, the narrative privileges uterus-bearing experience. For Onye's mother, the ultimate act of defiance is bearing and raising a daughter. Of Onye’s being female, Aro says “[Najeeba] must have demanded it the day you were conceived. Her demands obviously trumped your birth father's. If you had been a boy, he'd have had an ally instead of an enemy" (120). It is not the latent magic of Daib, but the will and power of Najeeba, which grants Onye her womanhood and her sorcery. The act used to oppress Najeeba becomes the tool through which she builds her own salvation (and, directly conjoins Onye’s gendered and heroic identities). Even faced with rape, Najeeba maintains agency over her body, shapes her own path, and survives.

While many hero's journeys are motivated by the victimization and often death of women, the victim in this journey is a woman who faces great trauma, but recovers her strength. Najeeba loses her voice for years after the rape, but survives alone in the desert for years through pregnancy, birth, and the first several years of her daughter's life. She is the victim of rape, but she is never dehumanized by the experience, never objectified by the narrative. Her voice returns once her daughter passes the Mystic Points (135), and she goes on to project her spirit to villages her daughter will travel through so they know of her coming and her quest (206), and to transform into a mythic desert fire lizard to show Onye a way out of the desert (286). She’s a 
busy, complex character with power, growth, and change. She is shaped by the crime committed against her, but not broken by it.

Women are the heroes of the story. When assuming the role of hero, they do not lose their feminine signifiers. They are never defeminized to justify or communicate strength. From small gestures, like buying new garments on the road or perfuming their bodies, to larger, like Onye’s friends caring for her after her passing of the Great Points, or sharing secrets that even Mwita is not privy to, the ties to womanhood help female characters maintain a sense of self, and of community. There is not shame in Onye leaning on her friends, crying on Mwita's shoulder, sharing the burden of her grief. The strength of Onyesonwu's friendships are integral to her success in her journey, and demonstrates that Onye’s power isn't generated from stoicism, and her power is not equated with masculinity. Onye’s emotions, and her womanhood, are her source of strength.

The men, sometimes effectively, sometimes ineptly, function mostly as support systems for the women. Mwita, the most central male character, is a prime example. His character helps Onye realize the strength she already has, taking a role that is supportive, but with humility. He does not try to fix her problems, nor manufacture solutions for her—-he merely gives her his wisdom and his presence in a way that compliments her own. Mwita's character subverts some of the fantasy-established archetypal gender roles. While Onyesonwu is a fierce warrior, Mwita is a healer. He has the ability to care for Onye as she pushes her body to the limits. He is able to interpret needs, to nurture and mend. While there is nothing intrinsically feminine about these skills and traits, within fantasy, the role of nurturer and healer is usually gendered female, while the mantle of warrior is often worn by men. In this way, his place in the narrative is feminized, a fact which his character actively questions and interrogates during his relationship with Onye. 
He, the closest and dearest love of the protagonist, is not immune to falling into the rhetoric of tradition. "I should be the sorcerer and you should be the healer. That's how it's always been between a man and woman,” he tells Onye during a fight (253). Later, Onye muses, “Those old beliefs about the worth and fate of men and women, that was the only thing I didn't like about Mwita. Who was he to think he was entitled to be the center of things just because he was male?”

With Mwita’s healing and Onyesonwu's sorcery, both characters have the potential to affect not just their own bodies in a restitutive capacity, but the bodies of those around them. Between the connotations of violence they bear on their skin and the abilities and powers they possess is a tension between the positive and negative forces on the bodies of the protagonists as well as pressure and complication to the archetypal, raced, gendered roles they are born into. Onye must literally wear the violence of her Nuru father on her body; yet, her experience of her own body is arguably the most liberated of any of the characters. Onye is Eshu, meaning she is a shapeshifter who can change her form as she pleases. She becomes at times a tiger, a fire lizard, a sphinx--all powerful creatures. As a character discriminated against because of her womanhood and her Ewu skin, her ability to transform gives her freedom. Part of her power is her ability to escape her body and the limitations society places upon it, and to change it to suit her pleasure.

\section{$\underline{\text { Conclusion }}$}

Who Fears Death is a story about a woman telling you a story about her quest to change the book that told stories about herself and her people. The evils in it are not abstracted. There is no mythical dark cloud, there is no pure evil, only hate, combined with the mind and power to 
actualize it. The villains of this novel are not contorted into unrecognizable menaces--the threats they represent and the motivation for those threats are anchored in something very familiar. The signification in Who Fears Death mirrors signification in the real world. As a product, the heroine's motivation to combat this evil is more than a sense of duty or a savior complex, it's identity-driven. It's personal, built not on moral imperitives, but survival. Onyesonwu's quest is largely fueled by a need to avenge her conception; her quest is to kill her evil father, and to rewrite the story that justifies her and her people's subjugation.

Within the novel, Okorafor unpacks real-world colonial theory, complicates racial signification, interrogates the boundaries of gender, but ultimately creates an intersectional text that shows modes of healing and resistance within systems of oppression. For a dystopia, Who Fears Death is surprisingly optimistic. It presents an acknowledgment of oppression, of prejudice, without an acceptance of that reality. Through the character's arcs, Okorafor presents courses of action--ones that involve challenging assumptions, rebelling against oppression, and rewriting societal narratives of difference and inequality. As Lisa Yaszek writes, “Afrofuturism is not just about reclaiming the history of the past, but about reclaiming the history of the future" (47). In Okorafor's world, women are heroes, colonialism is purged from the collective consciousness, and magic is real. Her novel forges a path for the genre of speculative fiction, and navigates a new kind of post-colonial reality. For what comes next, we should all look forward.

\section{$\underline{\text { Works Cited }}$}

Attebery, Brian. Stories about Stories: Fantasy and the Remaking of Myth. Oxford. 
University Press, 2014.

Bould, Mark. "The Ships Landed Long Ago: Afrofuturism and Black SF." Science Fiction Studies (2007): 177-186.

Burnett, Joshua Yu. "The great change and the great book: Nnedi Okorafor's postcolonial, post-apocalyptic Africa and the promise of black speculative fiction." Research in African Literatures 46.4 (2015): 133-150.

Campbell, Joseph. The Hero with a Thousand Faces. Vol. 17. New World Library, 2008.

Gray, Thomas R., and Nat Turner. "The Confessions of Nat Turner." (1831).

Hall, Stuart. "The Spectacle of the Other." Discourse Theory and Practice: A Reader (2001): 324-344.

Hopkinson, Nalo. So Long Been Dreaming: Postcolonial Science Fiction \& Fantasy. Arsenal Pulp Press, 2015.

Hua, Anh. "Black diaspora feminism and writing: memories, storytelling, and the narrative world as sites of resistance." African and Black Diaspora: An International Journal 6.1 (2013): 30-42.

Johnson, Walter. Soul by Soul. Harvard University Press, 2009.

Langer, Jessica. Postcolonialism and Science Fiction. Springer, 2011.

Lichtenberg, Judith. "The Ethics of Retaliation." Philosophy \& Public Policy Quarterly 21.4 (2001): 4-8.

Okorafor, Nnedi. Who Fears Death. Penguin, 2011.

Timmerman, John H. Other Worlds: The Fantasy Genre. Popular Press, 1983.

Yaszek, Lisa. "Afrofuturism, science fiction, and the history of the future." Socialism and Democracy 20.3 (2006): 41-60. 
